\title{
THERMOSTABLE SACCHAROGENIC AMYLASE PRODUCED UNDER SUBMERGED FERMENTATION BY FILAMENTOUS FUNGUS Penicillium purpurogenum
}

\author{
Tony Márcio Silva, Maurício de Oliveira, Alexandre Favarin Somera, João Atílio Jorge, Héctor Francico Terenzi, Maria \\ de Lourdes T. M. Polizeli, Luis Henrique Souza Guimarães *
}

Departamento de Biologia, Faculdade de Filosofia, Ciências e Letras de Ribeirão Preto, Universidade de São Paulo, Ribeirão Preto, SP, Brasil.

Submitted: May 11, 2010; Approved: January 31, 2011.

\begin{abstract}
The effect of several nutritional and environmental parameters on Penicillium purpurogenum growth and sacharogenic amylase production was analyzed. High enzyme levels (68.2 $\mathrm{U} \mathrm{mg}^{-1}$ ) were obtained with Khanna medium at initial $\mathrm{pH} 6.0$, incubated at $30^{\circ} \mathrm{C}$ for 144 hours. The optimum $\mathrm{pH}$ and temperature activities were 5.0 and $65^{\circ} \mathrm{C}$, respectively. The enzyme presented a half-life $\left(\mathrm{t}_{50}\right)$ of $60 \mathrm{~min}$, at $65^{\circ} \mathrm{C}$. Only glucose was detected after 24 hours of reaction using soluble starch as substrate.
\end{abstract}

Key words: amylase, Penicillium purpurogenum, submerged fermentation

Starch-based foods like bread, pasta, potatoes and rice contribute approximately with one third of the total weight of our dietary intake. Starch also is a major raw material for the manufacture of several products including glucose syrup and sweeteners (13). Starch is hydrolyzed to glucose, maltose and maltooligosaccharides by four groups of amylases according to Van der Maarel et al. (2002) (16). The first one is formed by the endoamylases (EC 3.2.1.1) witch cleave $\alpha-1,4$ glycosidic bonds in amylose, amylopectin and related polysaccharides, but not the $\alpha-1,6$ linkages. Enzymes belonging to the second group are known as exoamylases and successively act at the no reducing end. These enzymes preferentially act either on $\alpha-1,4$ bonds ( $\beta$-amylase; EC 3.2.1.2) or on both $\alpha, 1-4$ and $\alpha, 1-6$ glycosidic bonds (glucoamylase; EC 3.2.1.3 and $\alpha$-glucosidase; EC 3.2.1.20). Another group is constituted by the debranching enzymes known as pullulanase (EC 3.2.1.41) and isoamylase
(EC 3.2.1.68), which acts specifically on $\alpha-1,6$ bonds. The last ones are transferases that cleave the $\alpha-1,4$ glycosidic bond of the donor molecule and transfer part of the donor to a glycosidic acceptor leading to the formation of a new glycosidic bond $(14,16)$.

Amylases have been produced by bacterial, fungal and other organisms $(7,17,18)$. The industrial demand for these enzymes is limited to specific applications in the food industry, where fungal amylases are preferred over other microbial sources, mainly because of their high accepted GRAS status (13). In this study we investigated the production of saccharogenic amylases by the new filamentous fungus $P$. purpurogenum strain under submerged fermentation and reported some cultivations conditions. The products of starch hydrolysis after a treatment with crude enzyme were determined. 
For this purpose the $P$. purpurogenum strain isolated from soil and identified by the laboratory of molecular genetic of microorganism (Department of Genetic, FMRP-USP, Ribeirão Preto, Brasil) was maintained at $30^{\circ} \mathrm{C}$, on slants of solid $4 \%$ (w/V) oatmeal baby food (Quaker) media, at $4^{\circ} \mathrm{C}$. The microorganism cultures were obtained by the addition of $1 \mathrm{~mL}$ solution of spore suspension $\left(10^{7}\right.$ conidia/mL $)$ in Khanna medium (9) added with $1 \%$ starch (w/V) or other carbon source (rice straw, oat meal, crushed corn cob, crushed corn, "Maizena", maltose, penetrose, amilopectin, raffinose, lactose and glucose) at different temperatures $\left(20^{\circ} \mathrm{C}-40^{\circ} \mathrm{C}\right)$ for 144 hours under stationary condition.

After cultivation, the cultures were harvested and the filtrate was used for the determination of amylase activity using $1 \%(\mathrm{w} / \mathrm{V})$ starch $\left(\right.$ Sigma $^{\circledR}$ and Reagen $\left.{ }^{\circledR}\right)$ as substrate $(0.1$ $\mathrm{M}$ sodium acetate buffer, $\mathrm{pH} 5.0)$ at $60^{\circ} \mathrm{C}$. The reducing sugars were quantified according to Miller (1959) (11). The enzymatic activity was also determined using others substrates as glycogen, amylopectin, maltose, maltotriose, $\alpha$-PNPG and sucrose in the same concentration and conditions described for starch. One unit of activity was defined as the amount of released reducing sugar at initial rate of $1 \mu \mathrm{mol} \mathrm{min}{ }^{-1}$ in the assay condition. Protein was determined according to Lowry et al. (1951) (10) and expressed as mg of protein.

The enzyme stability to $\mathrm{pH}$ was determined at a range from 3.0 to 9.0 using $100 \mathrm{mM}$ McIlvaine buffer and the stability to temperature from $55^{\circ} \mathrm{C}$ to $70^{\circ} \mathrm{C}$ for 4 hours, both in the same conditions described above. The hydrolysis products of soluble starch $(1 \%$; w/V) were analyzed by thin-layer chromatography (TLC) using buthanol/ethanol/water (5:3:2; $\mathrm{V} / \mathrm{V} / \mathrm{V})$ as mobile phase. It was used $1 \%(\mathrm{w} / \mathrm{V})$ of glucose, maltose and maltotriose solutions as standard.

All experiments were conducted in triplicate and the results were present as media values \pm standard deviation (SD).

High levels of amylase production $\left(68.2 \pm 1.8 \mathrm{U} \mathrm{mg}^{-1}\right)$ were obtained when the fungus was grown in Khanna medium (9) added of $1 \%(w / V)$ soluble starch as the only carbon source in stationary condition for 120 hours. This time is relatively short, what can carry lower cost of production in a wide scale. The production in this condition was 1.6-fold higher than the one obtained in agitation condition. On the other hand, great quantities of glucoamylase were also secreted using amylopectin $\left(63.2 \pm 1.7 \mathrm{U} \mathrm{mg}^{-1}\right)$, maltose $\left(36.0 \pm 0.9 \mathrm{U} \mathrm{mg}^{-1}\right)$, ground corn $\left(32.5 \pm 0.8 \mathrm{U} \mathrm{mg}^{-1}\right)$ and oatmeal $(20.0 \pm 1.0$ $\mathrm{U} \mathrm{mg}^{-1}$ ) as carbon source. Despite, the production was also observed with "Maizena", rice straw and corncob. Starch and derivates have been described as the most adequate carbon source for amylase production. In this case, the utilization of agricultural residues or starch processing, which contain enough quantities of residual starch and the low cost of process, constitute one of the most viable option. Thus, the results showed for the amylase production by $P$. purpurogenum on media supplemented with soluble starch, amylopectin, maltose and penetrose are in accordance with the literature.

The effect of initial $\mathrm{pH}$ of culture medium on the production of amylases, at a range of 4.0 - 7.0 was determined and the highest enzymatic production by the fungus was obtained with initial $\mathrm{pH}$ adjusted for 5.0 (Fig. 1A). These results are similar to those reported for Aspergillus sp. A3 (3) and contrasting to those obtained for amylases produced by $A$. fumigatus (6) and A. oryzae Ahlburg (Cohen) 1042.72 (1). In addition, the maximum enzyme production was at $30^{\circ} \mathrm{C}$ (Fig. 1B), although the highest fungal growth was obtained at $25^{\circ} \mathrm{C}$ (data not shown). This fact shows that the fungus can be considered mesophilic.

Most of fungal amylases are produced by mesophilic organisms growing in a range of temperature varying from $25^{\circ} \mathrm{C}$ to $37^{\circ} \mathrm{C}$ (7). Same optimal temperature for amylase production was observed for mesophilic molds A. oryzae and A. tamarii, $35^{\circ} \mathrm{C}$ for the enzyme of Rhizopus oligosporos and Aspergillus sp. and $25^{\circ} \mathrm{C}$ for the amylase of Cryptococcus flavus $(2,4,8,12,18)$. Optima of $\mathrm{pH}$ and temperature were estimated as 5.0 and $65^{\circ} \mathrm{C}$, respectively (Fig. $1 \mathrm{C}$ and $1 \mathrm{E}$ ). In addition, the enzyme was stable in a wide range of $\mathrm{pH}$ 
$(4.0$ - 8.0) (Fig. 1D). The enzyme was completely stable for four hours when incubated at $55^{\circ} \mathrm{C}$ and showed a good stability at $60^{\circ} \mathrm{C}$. The enzyme maintained $50 \%$ of activity in $60 \mathrm{~min}$ at $65^{\circ} \mathrm{C}$ and $30 \mathrm{~min}$ at $70^{\circ} \mathrm{C}$ (Fig. 1F).
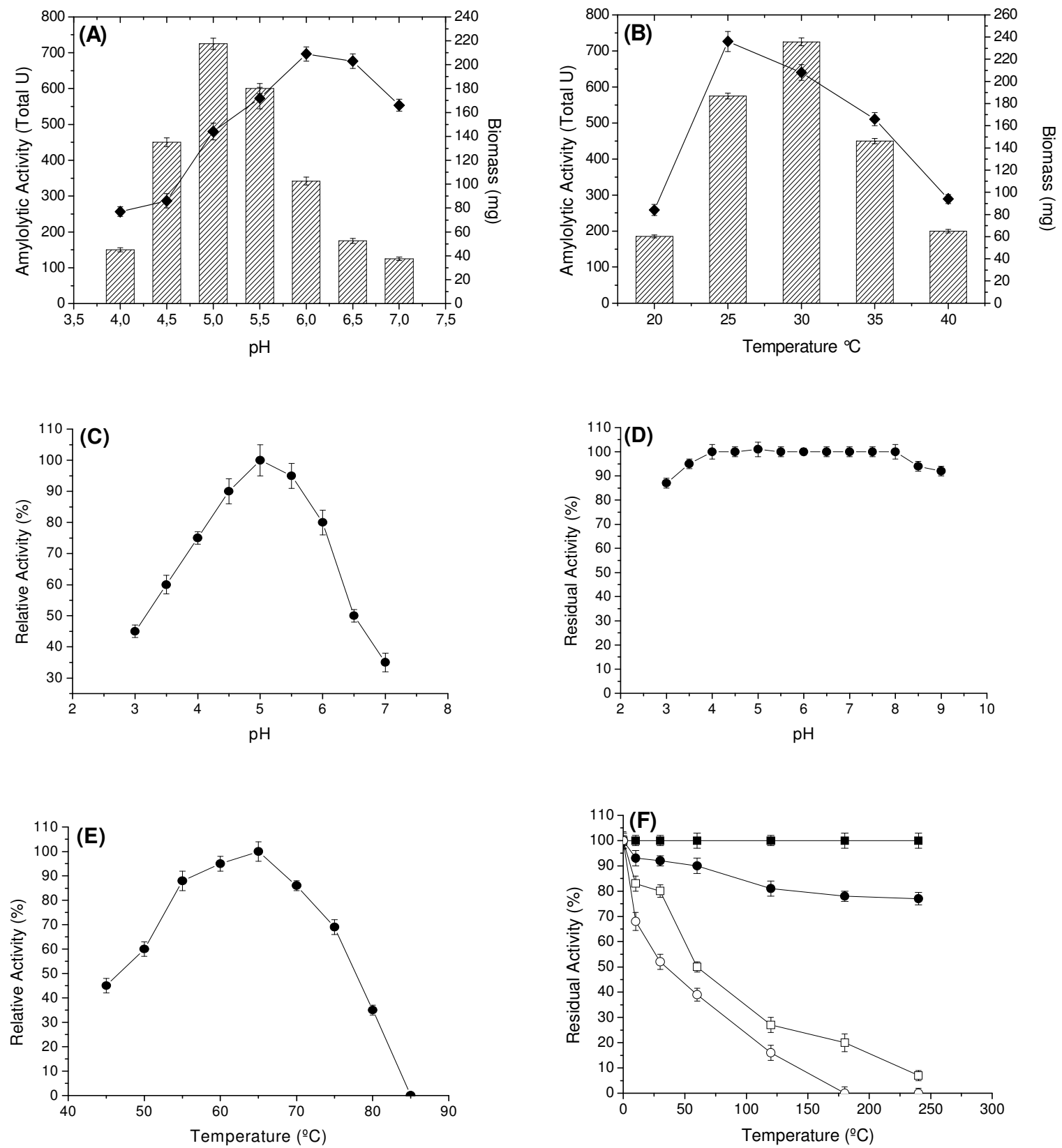

Figure 1. Influence of the initial $\mathrm{pH}(\mathrm{A})$ and temperature (B) on the amylase production and biomass (-), optimum of $\mathrm{pH}(\mathrm{C})$ and temperature (E) for enzymatic activity and enzyme stability to $\mathrm{pH}(\mathrm{D})$ and temperature $(\mathrm{F})$. Symbols for $(\mathrm{F}): 55^{\circ} \mathrm{C}(\boldsymbol{\square}), 60^{\circ} \mathrm{C}(\boldsymbol{\bullet})$, $65^{\circ} \mathrm{C}(\square)$ and $70^{\circ} \mathrm{C}(\mathrm{O})$. 
The determination of physical-chemical characteristics of the enzymes involved in biotechnological processes is important, having in mind the optimization of the activity, with possibilities for future applications in industrial scale. Each enzyme presents a great $\mathrm{pH}$ of performance, which is directly related with the native three-dimensional conformation that is influenced by $\mathrm{pH}$ and by ions in the solution. Fungal glucoamylases are usually active in acid $\mathrm{pH}$. The optimum $\mathrm{pH}$ for the saccharorogenic amylase of P. purpurogenum was 5.0, similar to the one observed for glucoamylase from A. terreus (5). The activity was acid-alkaline tolerant, maintaining itself stable by two hours in $\mathrm{pH}$ from 4.0 to 9.0. These data are interesting and they make the use of this enzyme in process which involves possible $\mathrm{pH}$ variations. The optimal temperature for the saccharogenic amylase from $P$. purpurogenum was $65^{\circ} \mathrm{C}$. This temperature is superior to those presented for glucoamylases from A. terreus $\left(60^{\circ} \mathrm{C}\right)(5)$ and Aspergillus sp. AS-2 $\left(50^{\circ} \mathrm{C}\right)(15)$. The amylase was totally stable for 4 hours at $55^{\circ} \mathrm{C}$, maintaining $80 \%$ of its activity after
4 hours and $50 \%$ after $60 \mathrm{~min}$, at $65^{\circ} \mathrm{C}$. These results reinforce the potential of this enzyme for the applications in processes that involve elevated temperatures.

The enzyme showed excellent capacity to hydrolyze different substrates with a higher action on soluble starch $\left(\right.$ Sigma $^{\circledR}$ and Reagen $^{\circledR}$ ), glycogen, amylopectin, maltose, maltotriose and amylose (data not shown). The capacity to hydrolyze starches of long chain and glycogen allows inferring that this enzyme is a glucoamylase, but on the other hand the inability to hydrolyze $\alpha$-PNPG and sucrose excludes the possibility of the amylase to be characterized as $\alpha$-glucosidase, once these enzymes have specific action on these substrates. Other evidence that shows that the enzyme produced by $P$. purpurogenum is a glucoamylase was the presence of glucose as the only hydrolysis end-product from starch, after 24 hours of assay (Fig. 2). The capacity of breaking the starch in just glucose after long periods, and the incapacity of breaking synthetic substrate ( $\alpha-\mathrm{PNPG})$, assures that the enzyme is a glucoamylase (1,4- $\alpha$-D-glucan glucohydrolase).

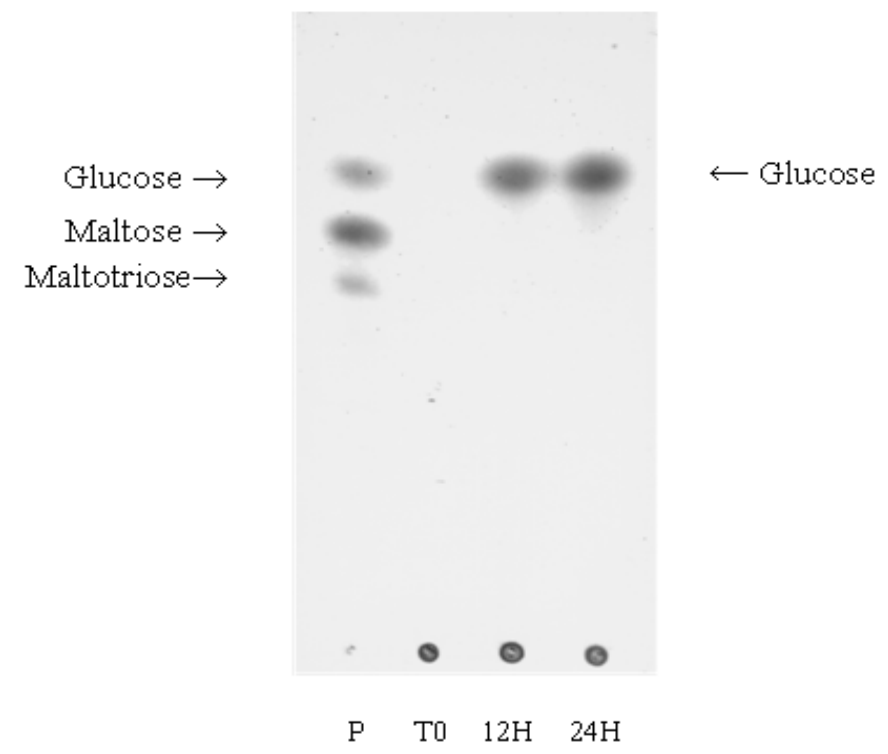

Figure 2. Analysis by TLC of the hydrolysis products of the soluble starch by the sacharogenic amylase produced by $P$. purpurogenum. S- standard; time of reaction: 0 hours (T0), 12 hours (12H) and 24 hours (24H). The mobile phase was buthanol/ethanol/water (5:3:2; v/v/v). Sugars were determined using 0.2\% orcinol in a methanol-sulfuric acid (9:1; v/v) solution. Glucose, maltose and maltotriose were used as standard. 


\section{ACKNOWLEDGEMENT}

This work was supported by grants from Fundação de Amparo à Pesquisa do Estado de São Paulo (FAPESP) and Conselho de Desenvolvimento Científico e Tecnológico (CNPq).

\section{REFERENCES}

1. Bennamoun, L.; Meraihi, Z.; Dakhmouche, S. (2004). Utilisation de la planification expérimentale pour 1'optimisation de la production de 1' $\alpha$ amylase par Aspergillus oryzae Ahlburg (Cohen) 1042.72 cultivé sur milieu à base de déchets d'oranges. J. Food Engineering., 64, 257-264.

2. Carlsen, M.; Nielsen, J.; Villadsen, J. (1996). Growth and $\alpha$-amylase production by Aspergillus oryzae during continuous cultivations. $J$. Biotechnol., 45, 81-93.

3. Ellaiah, P.; Adinarayana, K.; Bhavani, Y.; Padmaja, P.; Srinivasulu, B. (2002). Optimization of process parameters for glucoamylase production under solid state fermentation by a newly isolated Aspergillus species. Process Biochem., 38, 615-620.

4. Francis, F.; Sabu, A.; Nampoothiri, K.; Ramachandran, S.; Ghosh, S.; Szakacs, G.; Pandey, A. (2003). Use of response surface methodology for optimizing process parameters for the production of $\alpha$-amylase by Aspergillus oryzae. Biochem. Engin. J, 15, 107-115.

5. Ghosh, A.; Chatterjee, B.; Das, A. (1991). Purification and characterization of glucoamylases of Aspergillus terreus NA-170 mutant. J. Appl. Bacteriol., 71, 162-169.

6. Goto, C.E.; Barbosa, E.P.; Kistner, L.C.L.; Ganda, R.F.; Arrias, V.L.; Peralta, R.M. (1998). Production of amylases by Aspergillus fumigatus. Rev. Microbiol., 29, 99-103.

7. Gupta, R.; Gigras, P.; Mohapatra, H.; Kumar, V.G.; Chauhan, B. (2003).
Microbiol $\alpha$-amylases: a biotechnological perspective. Process Biochem., 38, 1599-1616.

8. Jin, B.; Leeuwen, H.J.; Patel, B.; Doelle, H.W.; Yu, Q. (1999). Production of fungal protein and glucoamylase by Rhizopus oligosporus from starch processing wastewater. Process Biochem., 34, 59-65.

9. Khanna, P.; Sundari, S.S.; Kumar, N.J. (1995). Production, isolation and partial purification of xylanase from Aspergillus sp. World J. Microbiol. Biotecnol., 11, 242-243.

10. Lowry, O.H.; Rosebrough, N.I.; Farr, A.L; Randall, R.J. (1951). Protein measurement with the folin phenol reagent. J. Biol. Chem., 193, 265-175.

11. Miller, G.L. (1959). Use of dinitrosalicylic acid reagent for determination of reducing sugars. Anal. Chem., 31, 426-428.

12. Moreira, F.G.; Lima, F.A.; Pedrinho, S.R.F.; Lenartoviez, V.; Souza, C.M.S.; Peralta, R.M. (1999). Production of amylases by Aspergillus tamari. Rev. Microbiol., 30, 157-162.

13. Prakasham, R.S.; Subba Rao, C.H.; Sreenivas Rao, R.; Sarma, P.N. (2006). Enhancement of acid amylase production by an isolated Aspergillus awamori. J. Appl. Microbiol., 102, 204-211.

14. Silva, T.M.; Attili-Angelis, D.; Carvalho, A.F.A.; Da Silva, R.; Gomes, E. (2005). Production of sacharogenic and dextrinogenic amylases by Rhizomucor pusillus A 13.36. J. Microbiol., 43, 561-568.

15. Soni, K.S.; Kaur, A.; Gupta, K.J. (2003). A solid state fermentation based bacterial $\alpha$-amylase and fungal glucoamylase system and its suitability for the hydrolysis of wheat starch. Process Biochem., 39, 185192.

16. Van der Maarel M.J.; van der veen, B.; Uitdehaag, J.C.; Leemhuis, H.; Dijkhuizen, L. (2002). Properties and applications of starch-converting enzymes of the alpha-amylase family. J. Biotechnol., 94(2), 137-155.

17. Vihinen, M. and Mäntsälä, P. (1989). Microbial amylolytic enzymes. Crit. Rev. Biochem. Mol. Biol., 24(4), 329-418.

18. Wanderley, J.K.; Torres, G.A.F.; Moraes, P.M.L.; Ulhoa, J.C. (2004). Biochemical characterization of $\alpha$-amylase from the yeast Cryptococcus flavus. FEMS Microbiol. Lett., 231, 165-169. 